\title{
The Structural Genes for Three Drosophila Glue Proteins Reside at a Single Polytene Chromosome Puff Locus
}

\author{
THOMAS E. CROWLEY, MARTHA W. BOND, $†$ AND ELLIOT M. MEYEROWITZ* \\ Division of Biology, California Institute of Technology, Pasadena, California 91125
}

Received 27 September 1982/Accepted 14 January 1983

\begin{abstract}
The polytene chromosome puff at $68 \mathrm{C}$ on the Drosophila melanogaster third chromosome is thought from genetic experiments to contain the structural gene for one of the secreted salivary gland glue polypeptides, sgs-3. Previous work has demonstrated that the DNA included in this puff contains sequences that are transcribed to give three different polyadenylated RNAs that are abundant in third-larval-instar salivary glands. These have been called the group II, group III, and group IV RNAs. In the experiments reported here, we used the nucleotide sequence of the DNA coding for these RNAs to predict some of the physical and chemical properties expected of their protein products, including molecular weight, amino acid composition, and amino acid sequence. Salivary gland polypeptides with molecular weights similar to those expected for the 68C RNA translation products, and with the expected degree of incorporation of different radioactive amino acids, were purified. These proteins were shown by amino acid sequencing to correspond to the protein products of the 68C RNAs. It was further shown that each of these proteins is a part of the secreted salivary gland glue: the group IV RNA codes for the previously described sgs-3, whereas the group II and III RNAs code for the newly identified glue polypeptides sgs-8 and sgs-7.
\end{abstract}

Drosophila melanogaster begins life as a fertilized egg, which after a day of embryonic development hatches as a wormlike first-instar larva. After another day this larva molts and becomes a larger, second-instar larva; one further day leads to a second molt and the last stage of larval life, the third larval instar. This lasts two days, at the end of which the larval cuticle hardens to form a pupal case. After an immobile prepupal period, pupation and metamorphosis occur, resulting in an adult fly. The major synthetic activity of the salivary gland cells of the third-instar larva is the production of a set of about 10 polypeptides that are secreted into the lumen of the gland after synthesis and that at the end of larval life are expelled through the duct of the salivary glands and deposited on the surface upon which the larva rests. This protein secretion serves as a glue that causes the prepupa, and subsequently the pupa, to adhere to its substrate for the duration of the pupal period ( 5 , $8,15,16)$.

At the time of glue protein synthesis there are visible a number of prominent puffs, or actively transcribing sites, on the salivary gland polytene chromosomes. These are called the intermolt

† Present address: DNAX Research Institute, Palo Alto, CA 94304. puffs (3). Genetic experiments have identified four of these puffs as the probable loci of structural genes coding for four different glue polypeptides $(1,16,30,31)$. One of the largest of these puffs is at position $68 \mathrm{C}$ on the third chromosome; it has been correlated with the structural gene, $S g s-3$, of the secreted glue polypeptide sgs-3, a glycoprotein and a major glue component (fraction 3 [15, 16]; protein P1 [5]). Puffing at $68 \mathrm{C}$ correlates with transcription of the puff DNA (19), and regression of the puff is the direct result of an interaction of the puffed chromosomal region with the steroid hormone ecdysone $(4,10)$. Molecular cloning of the puff DNA has shown that it contains the coding sequences for three different polyadenylated RNA species, all abundantly present on polyribosomes in third-larval-instar salivary glands. These RNAs have been designated the group II, group III, and group IV RNAs. They measure 360,320 , and 1,100 nucleotides, respectively, are all coded in a single 5,000-base-pair region of the puffed DNA, and appear and disappear from the salivary glands coordinately (19). To understand the regulation of the steroid-repressed $68 \mathrm{C}$ gene cluster, it is necessary to know the function of the three RNAs coded by the 68C puff. Circumstantial evidence has implied that the group IV RNA is the sgs-3 messenger; two 
possibilities for the roles played by the two small RNAs have been proposed (19). One is that their translation products serve a regulatory function in the coordination of expression of the various unlinked glue structural genes; the other is that they translate to produce glue proteins. In this paper we demonstrate that the group IV RNA does indeed translate to produce sgs- 3 . In addition, we show that the group II and group III RNAs are mRNAs coding for two additional secreted glue proteins, here named sgs-8 and sgs-7. This brings to six the number of glue polypeptides whose structural genes have been located in previously described intermolt puffs and presents the first case in which more than one glue protein derives from a single puff.

\section{MATERIALS AND METHODS}

Materials. Aminophenylthioether paper was prepared according to the procedure of Seed (26). Oligodeoxythymidylic acid-cellulose was purchased from Boehringer Mannheim Biochemicals. RNase A (bovine pancreatic) was purchased from Sigma Chemical Co., DNase I was from Worthington Diagnostics, and ampholines were from LKB Instruments Inc. Cyanogen bromide was obtained from Eastman Kodak, and formic acid was from Fisher Chemical Co. Polaroid Coaterless Land Pack Film 667 was used for photography of stained gels. Escherichia coli RNA polymerase I was a gift from C. Parker. The cyanogen bromide cleavage products of myoglobin were provided by J. R. Bell. Phosphorylase A, bovine serum albumin, egg albumin, carboxypeptidase A, trypsinogen, $\beta$ lactoglobulin, and lysozyme were purchased from Sigma Chemical Co. The isoelectric point markers, which were prepared by British Drug House Chemicals, Ltd., were purchased from Gallard-Schlesinger. Dithiothreitol was obtained from Calbiochem. Iodoacetamide was purchased from Sigma and was recrystallized twice before use. Acetonitrile (UV) was obtained from Burdick and Jackson Laboratories. The Oregon R strain of flies contained the homozygous third chromosome of strain OR16f (19). The Formosa strain of flies was kindly provided by S. K. Beckendorf, Department of Molecular Biology, University of California, Berkeley.

Preparation of DNA filters. Plasmid DNAs were purified by $\mathrm{CsCl}$ equilibrium centrifugation as described by Meyerowitz et al. (18), sheared by heating to $100^{\circ} \mathrm{C}$ for $15 \mathrm{~min}$ in $0.3 \mathrm{~N} \mathrm{NaOH}$ (30 to $75 \mu \mathrm{g}$ of DNA per $\mathrm{ml}$ ), neutralized, and ethanol precipitated. The fragmented DNA was then dissolved at 0.4 to 1.0 $\mathrm{mg} / \mathrm{ml}$ in $80 \%$ dimethyl sulfoxide- $13 \mathrm{mM}$ citric acid-17 $\mathrm{mM}$ sodium phosphate $(\mathrm{pH} \mathrm{4.0)}$ and transferred to disks of aminophenylthioether paper $(1.1-\mathrm{cm}$ diameter) that had been freshly converted to diazophenylthioether paper (2). A 10- $\mu$ l sample of the DNA solution was spotted on each filter. After $20 \mathrm{~h}$ of incubation at $24^{\circ} \mathrm{C}$, the filters were washed in water at $24^{\circ} \mathrm{C}$, in $0.4 \mathrm{~N}$ $\mathrm{NaOH}$ at $37^{\circ} \mathrm{C}$, and again in water at $24^{\circ} \mathrm{C}$ and stored in $50 \%$ formamide-1 $\mathrm{M} \mathrm{NaCl}-20 \mathrm{mM}$ PIPES [piperazine$N, N^{\prime}$-bis(2-ethanesulfonic acid)] (pH 6.8)-0.02\% sodium dodecyl sulfate (SDS)-1 mM EDTA at $4^{\circ} \mathrm{C}$.

Purification of RNA. Late-third-instar larvae were frozen in liquid nitrogen and ground to a fine powder with a mortar and pestle. The tissue was solubilized in $20 \mathrm{mM}$ NaCl-20 mM Tris-hydrochloride (pH 7.5)-1\% SDS- $40 \mathrm{mM}$ EDTA and extracted with equal volumes of phenol and chloroform-isoamyl alcohol (100:1). The aqueous phase was extracted again with phenol plus chloroform and then with chloroform alone. The nucleic acid was ethanol precipitated and passed through an oligodeoxythymidylic acid-cellulose column in 0.5 $\mathrm{M} \mathrm{NaCl-10} \mathrm{mM} \mathrm{Tris-hydrochloride} \mathrm{(pH} \mathrm{7.4)-0.2 \%}$ SDS-1 mM EDTA. The column was washed with four volumes of the same buffer to remove unbound material, and the bound polyadenylated RNA was then eluted with $10 \mathrm{mM}$ Tris-hydrochloride $(\mathrm{pH}$ 7.4)-0.2\% SDS-1 mM EDTA.

Hybrid selection of RNA and translation in vitro. Polyadenylated larval RNA $(3 \mu \mathrm{g})$ was incubated with a 1.1-cm-diameter filter disk containing sheared DNA in $75 \mu \mathrm{l}$ of hybridization buffer ( $50 \%$ formamide, $1 \mathrm{M}$ $\mathrm{NaCl}, 20 \mathrm{mM}$ PIPES [pH 6.8], 0.2\% SDS, $1 \mathrm{mM}$ EDTA) at $42^{\circ} \mathrm{C}$ with gentle agitation for $20 \mathrm{~h}$. Unhybridized RNA was removed, and the filters were washed twice in $75 \mu$ l of hybridization buffer at $42^{\circ} \mathrm{C}$ for $20 \mathrm{~min}$ and then three times in $1 \mathrm{ml}$ of $0.2 \mathrm{M} \mathrm{NaCl}-20 \mathrm{mM}$ PIPES (pH 6.8)-0.2\% SDS- $1 \mathrm{mM}$ EDTA at $42^{\circ} \mathrm{C}$ for 5 min. The hybridized RNA was then eluted by shaking the filters in $75 \mu \mathrm{l}$ of $99 \%$ formamide at $56^{\circ} \mathrm{C}$ for 20 $\mathrm{min}$. The elution was repeated two more times, and the elutions were pooled (G. Guild, personal communication). After addition of $2 \mu \mathrm{g}$ of yeast tRNA as carrier, the eluted RNA was ethanol precipitated, dissolved in $2 \mu \mathrm{l}$ of water, and translated in a micrococcal nuclease-treated rabbit reticulocyte lysate (New England Nuclear Corp.), prepared as described by Pelham and Jackson (25). The total reaction volume was $6.5 \mu$ l. $\left[{ }^{35}\right.$ S $]$ cysteine or $\left[{ }^{35} S\right]$ methionine $(400$ to $1,100 \mathrm{Ci} /$ mmol; New England Nuclear) was used as the label in the translations, and the products were analyzed by SDS-polyacrylamide gel electrophoresis (SDSPAGE).

Labeling of proteins in vivo. Salivary gland proteins were labeled by injecting $\left[{ }^{35}\right.$ S $]$ cysteine into larvae or by culturing dissected salivary gland lobes in the presence of a radiolabeled amino acid. For injection, ${ }^{35}$ S]cysteine was dissolved at $83 \mu \mathrm{Ci} / \mu \mathrm{l}$ in culture medium $(10 \mathrm{mM}$ morpholinepropanesulfonic acid [ $\mathrm{pH}$ 7.0], $80 \mathrm{mM} \mathrm{NaCl}, 10 \mathrm{mM} \mathrm{KCl}, 1 \mathrm{mM} \mathrm{CaCl}, 0.1 \mathrm{mM}$ $\mathrm{MgCl}_{2}$ ), and $0.1 \mu \mathrm{l}$ was injected into each larva (20, 29). The larvae were then incubated on filter paper moistened with $10 \%$ sucrose at 22 to $24^{\circ} \mathrm{C}$ for $30 \mathrm{~min}$. Salivary gland lobes were then dissected from the larvae, and proteins were extracted as described below. For labeling in culture, dissected salivary gland lobes were incubated in a 5- to 10- $\mu$ d drop of culture medium containing $10 \mu \mathrm{Ci}$ of a radiolabeled amino acid per $\mu l(21,29)$. The specific activities (curies per millimole) of the amino acids (all from New England Nuclear) were as follows: $\left.{ }^{35} \mathrm{~S}\right]$ cysteine and $\left.{ }^{35} \mathrm{~S}\right]$ methionine, 400 to 1,100 ; $\left[{ }^{3} \mathrm{H}\right]$ proline, 102 to 139 ; $\left[{ }^{3} \mathrm{H}\right]$ isoleucine, 83; $\left[{ }^{3} \mathrm{H}\right]$ lysine, $68 ;\left[{ }^{3} \mathrm{H}\right]$ glycine, 53 ; and $\left[{ }^{3} \mathrm{H}\right]$ threonine, 5.3. After $30 \mathrm{~min}$ at 22 to $24^{\circ} \mathrm{C}$ the glands were removed from the labeling medium, and proteins were extracted from salivary gland lobes by one of the following four procedures. For one-dimensional SDS-PAGE the glands were heated for $5 \mathrm{~min}$ at $100^{\circ} \mathrm{C}$ in $0.5 \%$ SDS- $1 \% 2$-mercaptoethanol (1 to $2 \mu$ l per lobe). The solubilized proteins were then diluted with 10 volumes of $50 \mathrm{mM}$ Tris-hydrochloride $(\mathrm{pH}$ 
6.8)-0.5\% SDS-1\% 2-mercaptoethanol-10\% (vol/vol) glycerol. For two-dimensional isoelectric focusing (IEF)-SDS-PAGE the glands were heated for $5 \mathrm{~min}$ at $100^{\circ} \mathrm{C}$ in $0.5 \%$ SDS- $1 \%$ 2-mercaptoethanol (1 to $2 \mu \mathrm{l}$ per lobe). Urea was then added to give a final concentration of $8 \mathrm{M}$, and Nonidet P-40 (NP-40) was added to give a final concentration of $2 \%$. For two-dimensional nonequilibrium $\mathrm{pH}$ gradient electrophoresis (NEPHGE)-SDS-PAGE the glands were sonicated, and treated with RNase $A$ and then with DNase $I$ as described by O'Farrell (23). The proteins were then solubilized in $8 \mathrm{M}$ urea-5\% 2-mercapthethanol-1\% NP-40-1\% ampholines. For one-dimensional acidurea-PAGE the glands were sonicated and nuclease treated as above, and the proteins were reduced and alkylated as described by Korge (16), except that $6 \%$ iodoacetamide was used instead of $2.5 \%$ ethylenimine (12).

Labeled glue proteins were isolated by the following procedure. Larvae were injected with $\left[{ }^{35}\right.$ S]cysteine as described above or incubated for $3 \mathrm{~h}$ on filter paper moistened with $10 \%$ sucrose containing a labeled amino acid. $\left[{ }^{3} \mathrm{H}\right]$ threonine was spread on the filter paper at $0.43 \mu \mathrm{Ci} / \mathrm{cm}^{2}$, and $\left[{ }^{35} \mathrm{~S}\right]$ cysteine was spread at $3.4 \mu \mathrm{Ci} / \mathrm{cm}^{2}$. Larvae were then transferred to fresh filter paper and left there until pupation. The pupae were then removed, and pieces of the filter paper containing the secreted glue were excised and pooled (B. McGinnis and S. Beckendorf, Drosophila Information Service, in press). Glue proteins were then eluted from the paper by one of four methods. For SDSPAGE or IEF-SDS-PAGE the paper was heated for 10 min at $100^{\circ} \mathrm{C}$ in $50 \mathrm{mM}$ Tris-hydrochloride ( $\mathrm{pH} \mathrm{6.8)-}$ $0.5 \%$ SDS-1\% 2-mercaptoethanol-10\% (vol/vol) glycerol. For NEPHGE-SDS-PAGE the proteins were eluted from the paper by either heating for $10 \mathrm{~min}$ at $100^{\circ} \mathrm{C}$ in $0.05 \%$ SDS-5\% 2-mercaptoethanol or by sonicating in 5\% 2-mercaptoethanol, adding NP-40 to a final concentration of $0.05 \%$, and then heating for 10 min at $100^{\circ} \mathrm{C}$. For one-dimensional acid-urea-PAGE the paper was suspended in 5\% 2-mercaptoethanol, sonicated, and then heated for $10 \mathrm{~min}$ at $100^{\circ} \mathrm{C}$. This solution was then removed, and the paper shreds were washed in $8 \mathrm{M}$ urea-10 mM Tris-hydrochloride $(\mathrm{pH}$ 8.0)-5\% 2-mercaptoethanol-1 mM EDTA for $18 \mathrm{~h}$ at $24^{\circ} \mathrm{C}$ with gentle agitation. At this point the liquid was separated from the paper and dialyzed against $1 \mathrm{mM}$ Tris-hydrochloride $(\mathrm{pH} 8.0)$ for $18 \mathrm{~h}$ at $2^{\circ} \mathrm{C}$. The dialyzed protein solution was lyophilized to dryness, and the proteins were reduced and alkylated as described above.

Isolation of unlabeled glue proteins. Bloated salivary glands from late-third-instar larvae were transferred to $95 \%$ ethanol, causing the glue to form a solid plug. The hardened glue was then dissected free of salivary gland cells with tungsten needles (14). The isolated glue proteins were then reduced and alkylated as described above.

PAGE. One-dimensional SDS-PAGE was carried out by the method of Laemmli (17), two-dimensional IEF-SDS-PAGE was carried out by the method of O'Farrell (23), and two-dimensional NEPHGE-SDSPAGE was carried out by the method of O'Farrell et al. (24). IEF gels contained a mixture of $\mathrm{pH} 4$ to $6, \mathrm{pH}$ 5 to 7 , and pH 3.5 to 10 ampholines. NEPHGE gels contained $\mathrm{pH} 3.5$ to 10 ampholines. For preparative two-dimensional PAGE the SDS stacking gels were overlaid with SDS sample buffer $(63 \mathrm{mM}$ Tris-hydrochloride [pH 6.8], $2.3 \%$ SDS, $10 \%$ [wt/vol] glycerol, $1 \%$ agarose) containing $10 \mathrm{mM}$ sodium thioglycolate. The thioglycolate was included to scavenge free radicals or oxidants in the gels (M. W. Hunkapiller, E. Lujan, F. Ostrander, and L. E. Hood, Methods Enzymol., in press). One-dimensional acid-urea-PAGE was carried out on $8 \mathrm{M}$ urea-7\% polyacrylamide gels as described by Korge (16).

Analytical gels of radiolabeled proteins were fixed in $50 \%$ methanol-10\% acetic acid, treated with En ${ }^{3}$ Hance (New England Nuclear), dried under vacuum, and exposed to Kodak X-Omat AR5 film. Analytical gels of unlabeled proteins were fixed and stained in $0.25 \%$ Coomassie brilliant blue R-50\% methanol-10\% acetic acid and destained in $25 \%$ methanol- $10 \%$ acetic acid.

Determination of isoelectric points. Nondenaturing isoelectric focusing gels consisted of $5 \%$ polyacrylamide, $12.5 \%$ sucrose, and $2.4 \% \mathrm{pH} 3.5$ to 10 ampholines. The electrode solutions were $1 \mathrm{M}$ orthophosphoric acid and $1 \mathrm{M}$ sodium hydroxide. Proteins were loaded onto the anodes (acidic ends) of these gels, and the gels were run at $1,000 \mathrm{~V}$ for $1.5 \mathrm{~h}$. The marker proteins (British Drug House Chemicals) used were all highly colored and hence visible in the focusing gels without staining.

$\left[{ }^{35}\right.$ S]cysteine-labeled salivary gland proteins were mixed with $235 \mu \mathrm{g}$ of marker proteins and focused as described above. The focusing gel was then loaded onto an SDS gel, and second-dimension electrophoresis was carried out as described above with a $15 \%$ polyacrylamide separating gel. The slab gel was then fixed, stained with PAGE blue 83 (British Drug House), destained, treated with $\mathrm{En}^{3} \mathrm{Hance}$, and vacuum dried. The positions of the stained markers in the dried slab gel relative to the anode of the focusing gel were then determined. Radiolabeled salivary gland proteins were located by fluorography.

$\left[{ }^{3} \mathrm{H}\right]$ threonine-labeled salivary gland proteins were mixed with $235 \mu \mathrm{g}$ of marker proteins and focused as described above. After focusing, the distance of each marker protein from the anode was measured, and the gel was loaded onto an SDS gel. Second-dimension electrophoresis was performed as described above with a $10 \%$ acrylamide separating gel. The location of radiolabeled sgs-3 was determined by fluorography.

Isolation of labeled proteins from polyacrylamide gels. Salivary gland proteins were labeled in cultured glands and separated by preparative IEF-SDS-PAGE or NEPHGE-SDS-PAGE (see above). For isolation of ${ }^{3} \mathrm{H}$-labeled proteins, a small amount of $\left[{ }^{35} \mathrm{~S}\right]$ cysteinelabeled protein was added to the sample before electrophoresis. After electrophoresis, gels were washed briefly in water, transferred to Whatman 3MM paper, and covered with Saran Wrap. The gels were dried under vacuum at $80^{\circ} \mathrm{C}$ for 1.5 to $2.0 \mathrm{~h}$, and proteins were located by autoradiography. Spots containing proteins of interest were cut out of the gels and rehydrated. Proteins were electroeluted from the gel slices as described by Hunkapiller et al. (in press).

Amino-terminal sequence analysis of labeled proteins. ${ }^{3} \mathrm{H}$ - or ${ }^{35} \mathrm{~S}$-labeled proteins were reduced in $0.2 \mathrm{M}$ Trishydrochloride ( $\mathrm{pH} \mathrm{8.4)-20} \mathrm{mM} \mathrm{dithiothreitol} \mathrm{under}$ nitrogen in the dark at $37^{\circ} \mathrm{C}$ for $2 \mathrm{~h}$. The proteins were then alkylated by adding solid iodoacetamide to a final concentration of $50 \mathrm{mM}$ and incubating at $24^{\circ} \mathrm{C}$ in the 
dark for $15 \mathrm{~min}$. The Tris-hydrochloride and excess iodoacetamide were then removed by electrodialysis, and the proteins were subjected to automated Edman degradation on the spinning cup sequenator described by Hunkapiller and Hood (13). The fractions released by the sequenator were dried under vacuum, and each was resuspended in $0.5 \mathrm{ml}$ of acetonitrile. The radioactivity in each fraction was then quantitated by scintillation counting using $5 \mathrm{ml}$ of Aquasol 2 (New England Nuclear) per fraction.

\section{RESULTS}

Three 68C RNAs are mRNAs. The nucleotide sequence of the DNA coding for the three $68 \mathrm{C}$ RNAs is known, and from this sequence the amino acid sequences of the primary products expected from translation of these RNAs has been determined (Garfinkel, Pruitt, and Meyerowitz, submitted for publication). The expected properties of the three predicted peptides are as follows. Protein II, the primary translation product of the group II RNA, would be 75 amino acids long and would have a molecular weight of 7,704. It would contain $13 \mathrm{mol \%}$ cysteine residues and methionine residues at positions 1,13 , and 56 . Protein III, the primary product of translation of the group III RNA, would be expected to be 74 amino acids long and 7,849 in molecular weight, to contain $12 \%$ cysteine residues, and to have methionines at positions 1 and 73. Protein IV, the unprocessed product of the group IV RNA; should contain 307 amino acids and measure 32,080 in molecular weight. It is not expected to be as high in cysteine content as the other two proteins, only $6 \%$, but it should contain $15 \%$ proline and $42 \%$ threonine residues. Protein IV has only one methionine residue, at position 1 . All three of the proteins expected from translation of the 68C RNAs are therefore quite unusual: proteins II and III are small, cysteine rich, and relatively methionine poor; protein IV is unusually rich in proline and threonine.

To be certain that RNAs II, III, and IV are indeed mRNAs, and therefore that the predicted proteins II, III, and IV might be found in larval salivary glands, the RNAs were purified and translated in vitro. Cloned DNA representing sequences from each of the RNA groups was denatured and covalently bound to diazotized paper. The clones used were the cDNA clone adm109F4 for the group II RNA, the cDNA clone adm127C8 for group III RNA, and the genomic clone aDm2023, a Sall subclone which contains the entire coding sequence of the large RNA on a 2.4-kilobase fragment originally derived from $\lambda b D m 2002$, for the group IV RNA. These clones are described in detail by Meyerowitz and Hogness (19). Polyadenylated whole third-instar-larval RNA was hybridized with the DNA on these filters, nonspecifically bound RNA was washed away, and the bound RNA was eluted. This eluted RNA was added to a micrococcal nuclease-treated rabbit reticulocyte lysate and translated in the presence of either $\left[{ }^{35} \mathrm{~S}\right]$ methionine or $\left[{ }^{35} \mathrm{~S}\right] \mathrm{cysteine}$. Translation of group II RNA in the presence of $\left[{ }^{35} \mathrm{~S}\right]$ methionine gave no detectably labeled protein, as compared with a control translation without added RNA. Translation with $\left[{ }^{35}\right.$ S $]$ cysteine yielded a single protein species with an apparent molecular weight of 7,700, as measured by SDS-PAGE. $\left[{ }^{35}\right.$ S]methionine also failed to detectably label the translation product of RNA III. $\left[{ }^{35}\right.$ S]cysteine was incorporated into an RNA III-directed translation product of apparent molecular weight 7,200. Figure 1 shows the results of electrophoresis of these proteins. The group IV RNA also failed to cause detectable incorporation of methionine into protein; with $\left[{ }^{35} \mathrm{~S}\right] \mathrm{cys}-$ teine label radioactivity was converted into trichloroacetic acid-insoluble form, but the labeled protein did not enter SDS-polyacrylamide gels in electrophoresis experiments, as if it were insoluble in aqueous buffer. Thus, all three 68C RNAs are mRNAs, and they translate in vitro to polypeptides with some of the characteristics predicted from the RNA nucleotide sequences.

Third-instar salivary glands synthesize proteins similar to those translated in vitro from the 68C RNAs. The next step was to determine whether the predicted proteins II, III, and IV, or proteins deriving from post-translational modification of these unprocessed peptides, could be detected in third-instar salivary glands. Salivary glands were dissected from larvae and incubated in medium containing $\left[{ }^{35} \mathrm{~S}\right]$ cysteine for $20 \mathrm{~min}$ at room temperature, after which proteins were extracted from the labeled glands and subjected to electrophoresis in an SDS-15\% polyacrylamide gel. A number of bands appeared in autoradiographs of the gel; the two most heavily labeled bands migrated at apparent molecular weights of $5,000(5 \mathrm{~K})$ and $5.5 \mathrm{~K}$. When an equal number of salivary glands were incubated in an equivalent experiment using $\left[{ }^{35}\right.$ S $]$ methionine, these two bands also appeared in gel autoradiographs, but with manyfold-reduced intensity as compared with the $\left[{ }^{35} \mathrm{~S}\right]$ cysteine-labeled bands (data not shown). These two proteins are thus candidates for processed peptides coded by the group II and group III RNAs.

In a parallel experiment, dissected salivary glands were incubated with $\left[{ }^{3} \mathrm{H}\right]$ threonine, and the resulting labeled proteins were separated in an SDS-10\% polyacrylamide gel. The gel fluorograph showed only two very strongly labeled protein bands, at apparent molecular weights of $162 \mathrm{~K}$ and $112 \mathrm{~K}$. The strong threonine labeling indicates that one or both of these proteins may be the product of the group IV RNA, whereas 


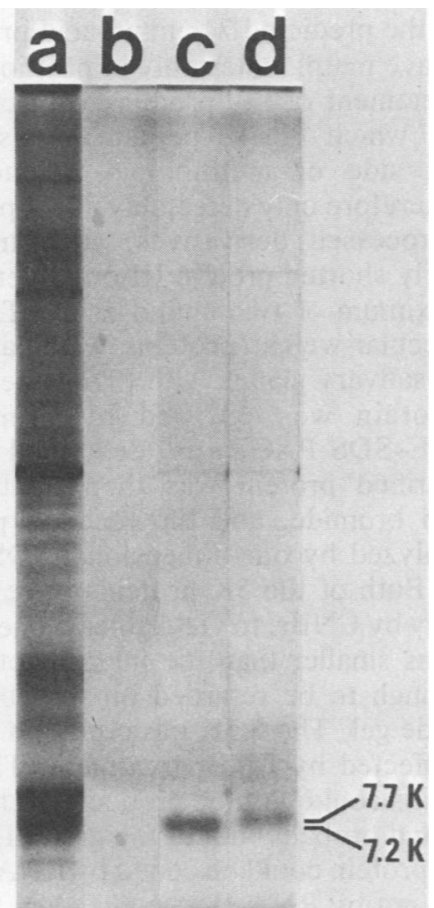

FIG. 1. In vitro translation of hybrid-selected RNAs. Polyadenylated RNA from late-third-instar larvae was hybridized to single-stranded cDNA clone DNA covalently bound to diazophenylthioether paper (see text). Bound RNA was eluted and translated in a rabbit reticulocyte in vitro translation extract with $\left[{ }^{35}\right.$ S $]$ cysteine. The translation products were heated for $5 \mathrm{~min}$ at $50^{\circ} \mathrm{C}$ in $50 \mathrm{mM}$ Tris-hydrochloride $(\mathrm{pH}$ 6.8)-0.5\% SDS-1\% 2-mercaptoethanol-10\% glycerol, separated by electrophoresis through a $15 \%$ polyacrylamide-SDS gel, and visualized by fluorography. Lanes: translation of total larval polyadenylated RNA (a) and translation with no added RNA (b), translation of RNA bound by adm109F4, the group II cDNA clone (c), and translation of RNA bound to adm127C8, the group III cDNA clone (d). The molecular weights of the proteins shown in lanes $\mathrm{c}$ and $\mathrm{d}$ were determined by comparison with the migration of protein standards (see footnote $a$ of Table 1).

the molecular weight implies that if this protein were translated from RNA IV, it must have undergone some post-translational modification, such as glycosylation, that increases apparent molecular weight in SDS gels (27).

To better characterize these $68 \mathrm{C}$ protein candidates, the migration of labeled salivary gland proteins in two-dimensional gel electrophoresis was examined. Two types of gels were used: in one type the first dimension was NEPHGE and the second dimension was SDS-PAGE (NEPHGE-SDS-PAGE [24]); in the second gel type the first dimension was an IEF gel and the second dimension was an SDS-polyacrylamide gel (IEF-SDS-PAGE [23]). Proteins from dissected salivary glands labeled in vivo with $\left[{ }^{35}\right.$ S]cysteine were loaded on both types of gel, and the resulting gel fluorographs and autoradiographs are shown in Fig. 2A and B. These show that the low-molecular-weight, cysteine-rich proteins that may be products of RNAs II and III are a group of three separable peptides: a $5.5 \mathrm{~K}$ peptide with a basic isoelectric point and two $5 \mathrm{~K}$ peptides with more acidic isoelectric points. The similar isoelectric points, molecular weights, and cysteine contents of the two $5 \mathrm{~K}$ proteins indicate that they may be encoded by the same mRNA and differ due to a post-translational modification.

$\left[{ }^{3} \mathrm{H}\right]$ threonine-labeled salivary gland proteins were separated by NEPHGE-SDS-PAGE and showed only the two proteins observed in onedimensional SDS-polyacrylamide gels: the $162 \mathrm{~K}$ and $112 \mathrm{~K}$ proteins that migrated in the NEPHGE dimension, indicating a basic isoelectric point (Fig. 2C). The identical migration of these proteins in the first dimension of the twodimensional gel and their heavy threonine labeling may indicate that they, too, are translation products of the same mRNA and differ due to a post-translational modification.

One further type of gel analysis of labeled salivary gland proteins was performed: IEF in the absence of the urea and NP-40 included in the first dimension of the IEF-SDS-PAGE gels. The reason for these nondenaturing IEF gels was to obtain an accurate measurement of isoelectric point for all of the putative $68 \mathrm{C}$ proteins; consequently, labeled salivary gland proteins were mixed with a series of unlabeled proteins of known pI, and IEF was performed on the mixture. The results of the pI measurements were as follows: the cysteine-rich $5.5 \mathrm{~K}$ protein had a pI of 10.3, the cysteine-rich $5 \mathrm{~K}$ proteins ran as one on these nondenaturing gels at a pI of 7.0, and the threonine-rich proteins migrated to a position slightly more basic than the most basic (pI 10.6) marker protein, indicating a pI of approximately 10.8 .

Partial amino acid sequence of the proteins confirms their $68 \mathrm{C}$ origin. There were thus five proteins that on the basis of molecular weight or amino acid composition appeared to be likely candidates for the products of the three $68 \mathrm{C}$ mRNAs. To determine whether any of these proteins was indeed derived from the cloned $68 \mathrm{C}$ puff, partial determinations of the amino acid sequences of all five proteins were made. The first step in this determination was to establish the approximate positions of the methionine residues in the three low-molecular-weight, cysteine-rich proteins. The predicted 75 -amino-acid protein from RNA II would be expected to have methionine residues at positions 1,13 , and 56, 

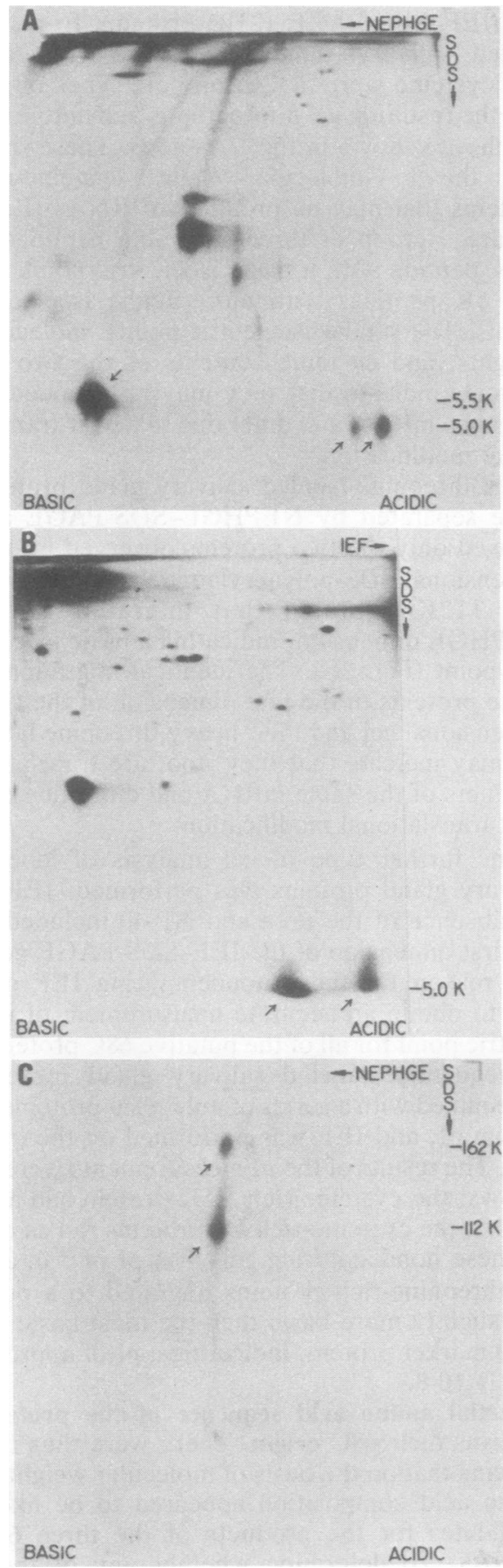

FIG. 2. Two-dimensional gel electrophoresis of salivary gland proteins. (A) Putative products of RNAs II and III. Thirty salivary gland lobes were labeled with [ $\left.{ }^{35} \mathrm{~S}\right]$ cysteine (see text), and one-third of the labeled protein was used. Proteins were denatured in $8 \mathrm{M}$ urea-5\% 2-mercaptoethanol-1\% NP-40 before electrophoresis. NEPHGE was from right to left for $2,000 \mathrm{Vh}$. The SDS gel was $15 \%$ polyacrylamide. Fluorographic exposure was for $11 \mathrm{~h}$. The putative whereas the predicted 74-amino-acid protein III should have methionines only at positions 1 and 73. A treatment of the proteins with cyanogen bromide, which breaks peptide bonds on the carboxyl side of methionine residues (11), should therefore only detectably affect protein II or its processed derivatives; such treatment would only shorten protein III or its derivatives by a maximum of two amino acids. The three low-molecular-weight proteins were labeled in cultured salivary glands with $\left[{ }^{35} \mathrm{~S}\right]$ cysteine, and each protein was purified by preparative NEPHGE-SDS-PAGE as described above. Each purified protein was then treated with cyanogen bromide, and the reaction products were analyzed by one-dimensional SDS-PAGE (Fig. 3). Both of the $5 \mathrm{~K}$ proteins were cleaved identically by $\mathrm{CNBr}$, to yield at least one peptide which was smaller than the intact peptide, but large enough to be retarded on the $20 \%$ polyacrylamide gel. The $5.5 \mathrm{~K}$ basic protein was not visibly affected by $\mathrm{CNBr}$ treatment. Thus, the $5 \mathrm{~K}$ proteins could both be products of the group II RNA and probably not of the group III RNA; the $5.5 \mathrm{~K}$ protein could be coded by RNA III, but probably not by RNA II.

To resolve this issue conclusively, the proteins were labeled with various radioactive amino acids in cultured salivary glands, purified by preparative two-dimensional gel electrophoresis, and subjected to sequential removal of amino-terminal amino acids by successive Edman degradations. The step of Edman degradation that released free labeled amino acid indicated the position of each labeled amino acid in the protein sequence. With an automated protein microsequenator (13), it was possible to determine whether any amino acid was present or absent in at least the first 20 amino acid positions of each protein. This determination was made

68C proteins are indicated by arrowheads. (B) Eight larvae were injected with $\left[{ }^{35}\right.$ S $]$ cysteine, their salivary gland lobes were dissected, and one-half of the protein from the gland lobes was loaded (see text). The proteins were denatured in $8 \mathrm{M}$ urea-1\% 2-mercaptoethanol-2\% NP-40 before electrophoresis. IEF was from left to right for 7,100 Vh. The SDS gel was $15 \%$ polyacrylamide. Exposure was for 18 days. The two proteins indicated by arrowheads correspond to the two $5 \mathrm{~K}$ spots in A. In the presence of urea and NP-40 these spots focus at a more acidic position in IEF gels than in nondenaturing gels, where they migrate as a single species (see text). (C) Putative protein IV products. Thirty salivary gland lobes were labeled with $\left[{ }^{3} \mathrm{H}\right]$ threonine, and one-fourth of the isolated protein was loaded (see text). Proteins were denatured in $8 \mathrm{M}$ urea-5\% 2-mercaptoethanol-1\% NP-40 before electrophoresis. NEPHGE was from right to left for 1,000 Vh. The SDS gel was $10 \%$ polyacrylamide. Exposure was for $42 \mathrm{~h}$. 
1a $1 \mathrm{~b} 2 \mathrm{a} 2 \mathrm{~b} 3 \mathrm{a} 3 \mathrm{~b}$

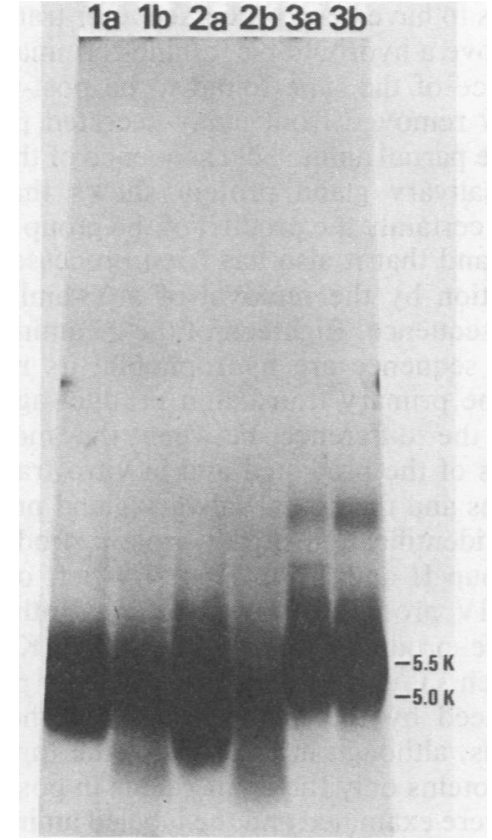

FIG. 3. Cyanogen bromide cleavage of the putative RNA II and RNA III products. Dissected salivary gland lobes were incubated with $\left[{ }^{35}\right.$ S $]$ cysteine and separated by preparative NEPHGE-SDS-PAGE as described in the text. The gel was vacuum dried, and autoradiography was performed. Individual proteins were then electroeluted from excised and rehydrated gel slices, lyophilized to dryness, and dissolved in 25 $\mu l$ of $70 \%$ formic acid. Five microliters of CNBr (300 $\mathrm{mg} / \mathrm{ml}$ ) in $70 \%$ formic acid was added, the reaction was incubated at $4^{\circ} \mathrm{C}$ for $16 \mathrm{~h}$, and $\mathrm{CNBr}$ and formic acid were removed by lyophilization. Untreated proteins (a) and $\mathrm{CNBr}$-treated proteins (b) were heated at $100^{\circ} \mathrm{C}$ for $3 \mathrm{~min}$ in $50 \mathrm{mM}$ Tris-hydrochloride (pH 6.8)-0.6 to $0.8 \%$ SDS-5\% 2-mercaptoethanol-10\% glycerol and then run on a $20 \%$ polyacrylamide-SDS gel. Proteins were detected by fluorography. Lanes: 1 , more acidic $5 K$ protein, $19,500 \mathrm{cpm}$ per lane; 2 , more basic $5 \mathrm{~K}$ protein, $26,900 \mathrm{cpm}$ per lane; $3,5.5 \mathrm{~K}$ protein, 38,800 cpm per lane.

for cysteine, lysine, and isoleucine in the first 30 amino-terminal amino acids of the $5 \mathrm{~K}$ putative protein II derivatives and for cysteine, proline, and lysine in the first $\mathbf{4 0}$ positions of the $5.5 \mathrm{~K}$ presumptive protein III product. The results are shown in Fig. 4 and 5. The sequences obtained showed both $5 \mathrm{~K}$ peptides to have the same amino acid sequence as far as it was determined and demonstrated the likelihood that both are translation products of the 68C RNA II. Furthermore, this amino-terminal sequence explains why the molecular weight of the in vivo RNA II product is lower than the molecular weight predicted from the nucleotide sequence of the RNA and the molecular weight of the peptide obtained by in vitro translation of the RNA II: the aminoterminal 23 amino acids of the predicted protein II are absent in the salivary gland protein derived from this RNA. Nineteen of the 23 missing amino acids are hydrophobic in character (7); thus the RNA II-derived salivary gland protein

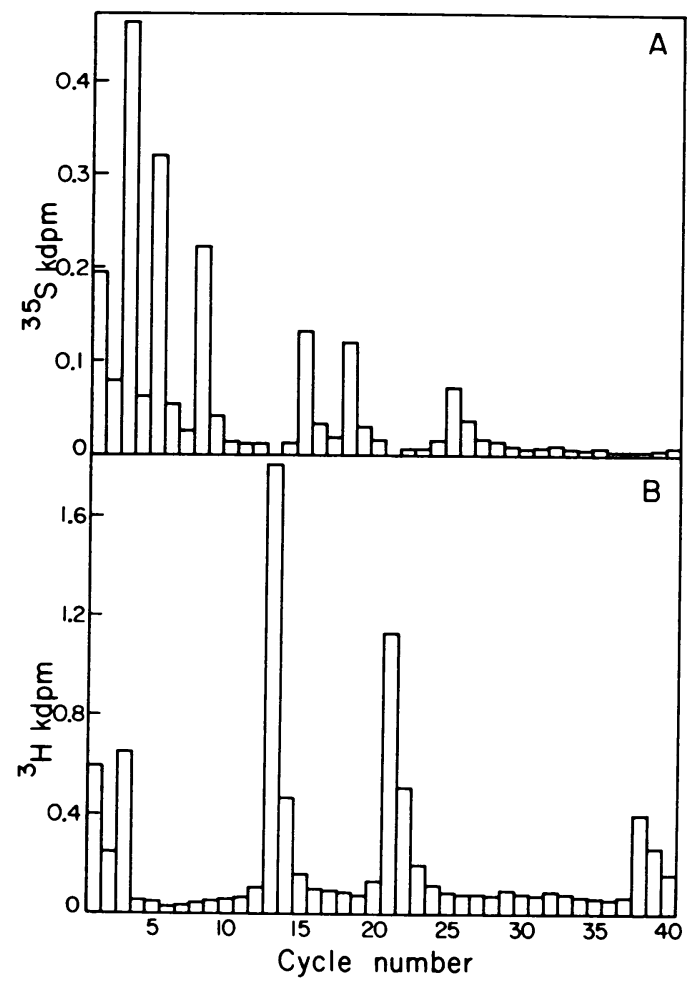

FIG. 4. Determination of the amino-terminal amino acid sequence of the putative group III RNA product. Thirty-two salivary gland lobes were labeled in medium containing $\left[{ }^{35} S\right]$ cysteine, and proteins were extracted as described in the text. $\left[{ }^{3} \mathrm{H}\right]$ lysine-labeled protein from 80 lobes was prepared in the same manner. One-sixteenth of the ${ }^{35} \mathrm{~S}$-labeled protein was mixed with one-half of the ${ }^{3} \mathrm{H}$-labeled protein, and the 5.5K cysteine-rich putative group III RNA product was purified from this mixture by preparative NEPHGE-SDS-PAGE (see text). The purified protein, containing $43,300{ }^{3} \mathrm{H} \mathrm{cpm}$ and $16,300{ }^{35} \mathrm{~S} \mathrm{cpm}$, was reduced and alkylated and then introduced into an automated spinning cup Edman microsequenator. The radioactivity of the resulting fractions was determined by scintillation spectrometry as described in the text. A Beckman LS $\mathbf{9 0 0 0}$ liquid scintillation counter was used to quantitate the counts per minute in a lowenergy window $\left({ }^{3} \mathrm{H}\right.$ plus $\left.{ }^{35} \mathrm{~S}\right)$ and in a high-energy window $\left({ }^{35} S\right)$. The counts per minute were then converted to disintegrations per minute by correcting for quenching, scintillation counter efficiency, and ${ }^{35} \mathrm{~S}$ disintegrations per minute in the low-energy window by using $n$-dioctyl- $\left[{ }^{35}\right.$ S]sulfide as a standard. (A) ${ }^{35} \mathrm{~S}$ released by the first $\mathbf{4 0}$ cycles of Edman degradation. (B) ${ }^{3} \mathrm{H}$ released. 
appears to have been processed after translation to remove a hydrophobic, amino-terminal signal sequence of the type found to be post-translationally removed from many secreted proteins (6). The partial amino acid sequence of the basic $5.5 \mathrm{~K}$ salivary gland protein shows that it is almost certainly the product of the group III 68C RNA, and that it also has been processed after translation by the removal of a 23-amino-acid signal sequence. Eighteen of the 23 amino acids in this sequence are hydrophobic; its removal from the primary translation product again explains the difference between the molecular weights of the predicted and in vitro translated peptides and the actual salivary gland protein.

The identification of the protein products of the group II and group III RNAs left only the group IV product to be identified. Both of the putative products, the $162 \mathrm{~K}$ and $112 \mathrm{~K}$ threonine-rich salivary gland proteins, were partially sequenced by the method used for the small proteins, although in the case of the threoninerich proteins only the amino acids in positions 1 to 20 were examined and the labeled amino acids used were cysteine and glycine. This limited sequence indicates clearly that both of the sequenced proteins derive from translation of the 68C group IV RNA, followed by removal of a 23-amino-acid signal sequence (Fig. 5). In this instance 15 of the 23 removed amino acids are hydrophobic.

Proteins are part of the glue secretion. The existence of secretion signal peptides in all of the 68C puff-derived proteins and the fact that the structural gene for at least one secreted salivary gland glue protein is thought to reside at the $68 \mathrm{C}$ locus made it seem reasonable to seek the $68 \mathrm{C}$ proteins in the secreted larval glue. To do this, mid-third-instar larvae were either fed or injected with radioactively labeled amino acids, and after puparium formation the secreted, radiolabeled glue was collected from the larval substrate and subjected to two-dimensional PAGE. When $\left[{ }^{35} S\right]$ cysteine was used as the radiolabel, the secreted glue showed labeled proteins that comigrated with the 5K RNA II products and with the basic 5.5K RNA III product (Fig. 6A and $B)$. When $\left[{ }^{3} \mathrm{H}\right]$ threonine was used, only one labeled glue protein was seen on gels; this comigrated with the $162 \mathrm{~K}$ threonine-rich product of the group IV RNA (Fig. 6C). Thus, each of the three RNAs transcribed from the $68 \mathrm{C}$ puff codes for a component of the secreted salivary gland glue.

The next question is whether these glue components have been previously recognized and named. From the similarity of our SDS-PAGE gels and those of Beckendorf and Kafatos (5), it seems possible that the group II and III RNA products are included in their glue protein frac- 


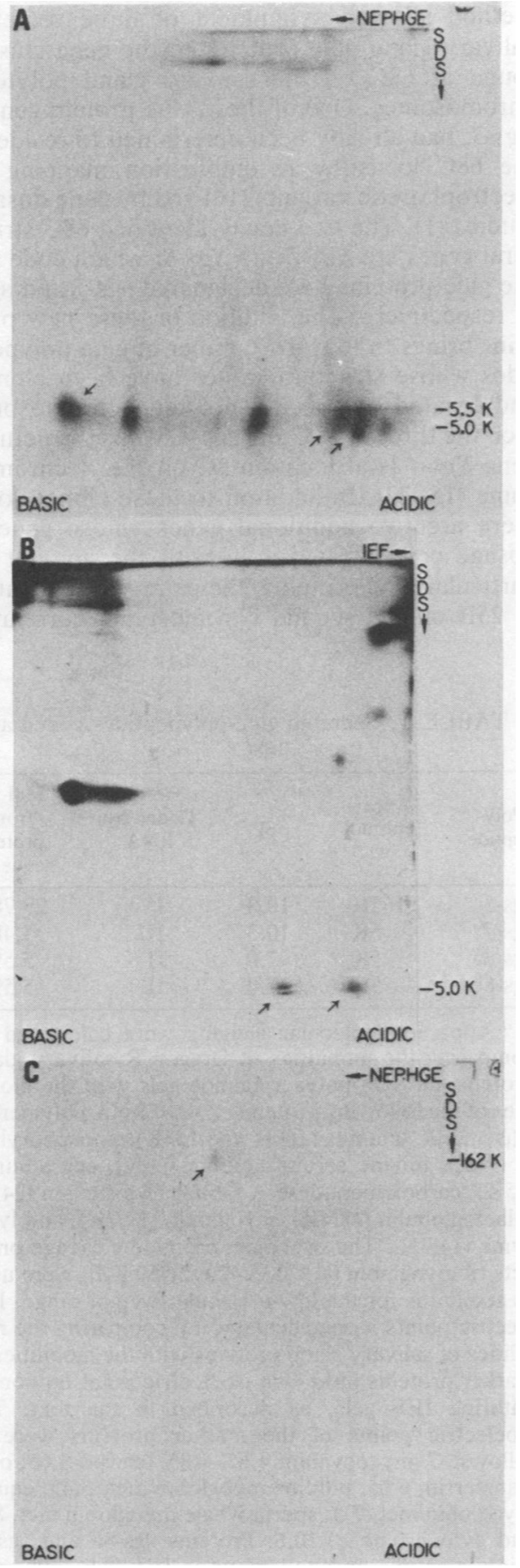

FIG. 6. Two-dimensional gel electrophoresis of secreted glue proteins. Glue proteins were labeled in vivo, purified after secretion as described in the text, and separated by two-dimensional gel electrophoresis. The resulting gel was analyzed by fluorography. (A) ${ }^{35}$ S $]$ cysteine-labeled proteins after migration in an NEPHGE first dimension and an SDS-15\% polyacryl- tion P6, although their measurement of molecular weight is quite different from ours. Korge's (16) analysis of salivary glues does not include these proteins. Since these proteins are newly identified as separate species, we named the salivary gland secretions translated from the $68 \mathrm{C}$ group II RNA sgs-8 and the $68 \mathrm{C}$ gene II $\mathrm{Sgs-8}$; we named the secretion protein derived from the group III RNA sgs-7, corresponding with the structural gene $S g s-7$. Since the group II RNA gives two different proteins on some types of gel, we subdivide sgs- 8 into sgs-8a, the more acidic of the two $5 \mathrm{~K}$ proteins, and sgs $8 \mathrm{~b}$, the more basic, as measured in urea- and NP-40containing IEF gels. This leaves the group IV protein product. Since genetic information indicates that the glue protein sgs-3 is coded by the 68C puff, it seemed likely that the gene IV product was the previously named sgs-3. Korge (17) showed that the Formosa wild-type strain of D. melanogaster produces an sgs-3 protein (3d) which, after alkylation, migrates more rapidly on acid-urea gels than the alkylated sgs- 3 protein (3a) of the Oregon $R$ wild-type strain. To show that the threonine-rich RNA IV product is sgs-3, we compared the electrophoretic migration of Coomassie blue-stained sgs-3 and $\left[{ }^{3} \mathrm{H}\right]$ threonine-labeled protein IV on acid-urea gels after alkylation. Figure 7A shows the migration of Coomassie blue stained, alkylated sgs-3 from the Oregon-R and Formosa wild-types; Fig. 7B is an autoradiograph showing that the threonine-rich alkylated Oregon- $R$ protein IV migrates identically in an acid-urea gel with sgs-3. Figure 7C demonstrates that Oregon-R protein IV and the homologous threonine-rich protein extracted from Formosa wild-type salivary glands show

amide second dimension. Proteins were denatured in 8 M urea-5\% 2-mercaptoethanol-1.5\% NP-40 before electrophoresis (electrophoresis parameters as in Fig. 2A). The proteins marked by arrows are as follows (from left to right): the $5.5 \mathrm{~K} 68 \mathrm{C}$ protein, the basic $5 \mathrm{~K}$ $68 \mathrm{C}$ protein, and the acidic $5 \mathrm{~K} 68 \mathrm{C}$ protein. The three additional, labeled proteins are part of the glue. These three comigrate with the known $68 \mathrm{C}$ products in the SDS-PAGE dimension, implying that their molecular weights are in the range of $5 \mathrm{~K}$ to $5.5 \mathrm{~K}$. They are present in $\left[{ }^{35} \mathrm{~S}\right]$ cysteine-labeled whole salivary gland proteins as well as in secreted glue and are far less abundant than the three identified $68 \mathrm{C}$ proteins in whole salivary glands. Their relation to the $68 \mathrm{C}$ proteins is unknown. (B) $\left[{ }^{35} \mathrm{~S}\right]$ cysteine-labeled proteins in an IEF-SDS-PAGE gel. Proteins were denatured in 8 M urea-1\% 2-mercaptoethanol-2\% NP-40 before electrophoresis (electrophoresis parameters as in Fig. 2B). (C) $\left[{ }^{3} \mathrm{H}\right]$ threonine-labeled proteins after NEPHGESDS-PAGE. Proteins were denatured in $8 \mathrm{M}$ urea0.3\% SDS-5\% 2-mercaptoethanol-4\% NP-40 before electrophoresis (electrophoresis parameters as in Fig. 2C). 


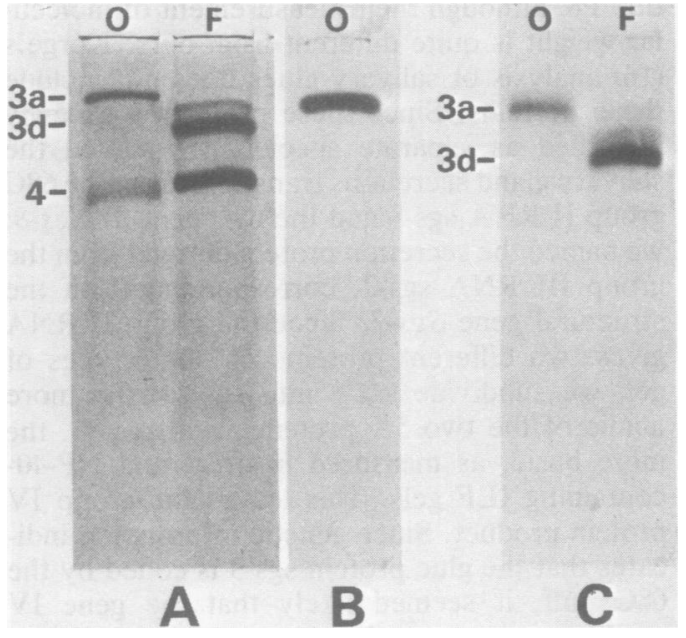

FIG. 7. Acid-urea gels of reduced and alkylated proteins. Proteins isolated from dissected glue plugs, secreted glue, or whole salivary glands were alkylated and separated by electrophoresis on acid-urea gels (see text). $\mathrm{O}$ is Oregon $\mathrm{R}$ wild type; $\mathrm{F}$ is Formosa wild type (see text). Electrophoresis was for $6.5 \mathrm{~h}$ at $100 \mathrm{~V}$. The proteins $3 \mathrm{a}$ and $3 \mathrm{~d}$ derive from alleles $S g s-3 a$ and $S g s-3 d$ of the $S g s-3$ structural gene (16). (A) Coomassie brilliant blue-stained proteins from dissected glue plugs of ethanol-fixed, bloated salivary glands. (B) $\left[{ }^{3} \mathrm{H}\right]$ threonine-labeled secretion protein detected by fluorography. (C) $\left[{ }^{3} \mathrm{H}\right]$ threonine-labeled salivary gland proteins detected by fluorography.

the same relative rates of migration, after alkylation and electrophoresis in acid-urea gels, as do the sgs- 3 proteins from the two strains. Thus, by two criteria, identical electrophoretic mobility and identical strain-dependent change in mobility, sgs-3 and the RNA IV product are the same. It is clear from comparison of our SDS-PAGE gels with those of Beckendorf and Kafatos (5) that their protein fraction $\mathrm{P} 1$ is equivalent to the group IV RNA product sgs-3. Table 1 summarizes the results described above.

\section{DISCUSSION}

In this work we have found the proteins coded by several sequenced genes of previously unknown function. The method employed was to predict certain of the physical and chemical properties expected of the protein products of these genes and then to find proteins with these properties in the tissue in which the genes were known to be active. This is a method which could be applied to many genes of known structure and tissue of expression, but unknown product, although with current techniques the successful application of this method is probably restricted to genes which transcribe abundant mRNAs. In the instance described here, this method allowed assignment of three secreted salivary gland glue proteins to the gene cluster found at $68 \mathrm{C}$ on the salivary gland polytene chromosomes. One of these glue protein genes, $S g s-3$, had already been determined to reside at the $68 \mathrm{C}$ locus by recombination mapping of electrophoretic variants (16) and by gene dosage studies (1). The two newly identified $68 \mathrm{C}$ structural genes are $S g s-7$ and $S g s-8$, which code for the glue proteins here designated sgs-7 and sgs8 , respectively. The addition of these new proteins brings to four the number of glue polypeptides whose structural genes have been cloned and located at specific polytene chromosome loci: the three at $68 \mathrm{C}$ and sgs-4, whose structural gene Sgs 4 is at location $3 \mathrm{C}$ on the $\mathrm{X}$ chromosome $(15,22)$. In addition to these cloned loci, there are two additional genes whose genetic dosage correlates exactly with the amount of particular glue proteins: the gene $S g s-1$, located at $25 \mathrm{~B}$ on the second chromosome, correlates

TABLE 1. Secreted glue polypeptides coded at $68 \mathrm{C}^{a}$

\begin{tabular}{lrrrr}
\hline $\begin{array}{c}\text { Poly- } \\
\text { peptide }\end{array}$ & $\begin{array}{c}\text { Appar- } \\
\text { ent mol } \\
\text { wt }\end{array}$ & pI & $\begin{array}{c}\text { Coded by } \\
\text { RNA }\end{array}$ & $\begin{array}{c}\text { Mol wt } \\
\text { from } \\
\text { protein } \\
\text { sequence }\end{array}$ \\
\hline sgs-3 & $162 \mathrm{~K}$ & 10.8 & IV & 29,782 \\
sgs-7 & 5K & 10.3 & III & 5,481 \\
sgs-8a & 5K & 7.0 & II & 5,592 \\
sgs-8b & 5K & 7.0 & II & 5,592 \\
\hline
\end{tabular}

a Apparent molecular weights were calculated by comparing the mobilities of Oregon $\mathbf{R}$ salivary gland proteins on SDS-polyacrylamide gels with the mobilities of the following proteins: $E$. coli RNA polymerase I ( $\beta$ and $\beta^{\prime}$ subunits, $160 \mathrm{~K}$ and $155 \mathrm{~K}$ ), phosphorylase A $(94 K)$, bovine serum albumin (66K), egg albumin (45K), carboxypeptidase A (35K), trypsinogen (24K), $\beta$-lactoglobulin (18.4K), myoglobin (17.2K), and lysozyme (14.3K). The cyanogen bromide cleavage products of myoglobin $(8,270,6,420,2,550$ [28]) were used as standards for the low-molecular-weight range. Isoelectric points were calculated by comparing the mobilities of salivary gland proteins with the mobilities of marker proteins of known isoelectric point on nondenaturing IEF gels, as described in the text. The isoelectric points of the marker proteins were as follows: $C$ phycocyanin, $4.65,4.85$; azurin, 5.65 ; ovotransferrin, 6.05; porcine myoglobin met, 6.45; equine myoglobin met, 7.3; sperm whale myoglobin met, 8.3; and cytochrome $c, 10.6$. Proteins sgs-8a and sgs-8b migrate as one on nondenaturing IEF gels, but separate into an acidic and a basic component in IEF gels containing urea and NP-40 (see text). The molecular weights derived from the protein sequence were calculated from a conceptual translation of the known RNA sequences (Garfinkel et al., submitted for publication), taking into account the fact that the amino-terminal 23 amino acids predicted from these sequences are absent in the mature salivary gland proteins. 
with production of glue protein sgs-1 (30), and Sgs-6, at 71C-F on the third chromosome, correlates with protein sgs-6 (31). It is virtually certain that these genes are glue protein structural genes. All six of the glue genes mapped so far correspond to prominent salivary gland polytene chromosome puffs present at the time when the glue proteins are being synthesized $(3,31)$. The 68C puff is distinguished from the others by being the only puff locus that is known to contain the structural genes for more than one glue protein.

Since the nucleotide sequences of the RNAs coding for each of the $68 \mathrm{C}$ are known, it is possible to calculate the molecular weight expected of these products. Table 1 includes the results of this calculation, based on the expected primary translation products from the $68 \mathrm{C}$ RNAs minus the 23-amino-acid signal peptide known to be removed from each protein before its secretion. The correspondence of measured and expected molecular weight is good for sgs-7 and sgs-8, but not for sgs-3. The reason for this is almost certainly glycosylation. sgs-3 is known to be an extensively glycosylated protein $(5,16)$, and such proteins migrate more slowly than would be expected from their molecular weight in SDS-polyacrylamide gels (27). Glycosylation also provides a plausible explanation for the two forms of sgs-3 seen in salivary glands after 20 min of $\left[{ }^{3} \mathrm{H}\right]$ threonine labeling of the isolated tissue. Since only the form that migrates in gels with an apparent molecular weight of $162 \mathrm{~K}$ is found in secreted glue, it may be that the form migrating at $112 \mathrm{~K}$ is a less glycosylated precursor of the mature protein, and that labeling of the proteins of isolated salivary glands followed by an incubation in unlabeled amino acids might show conversion of the apparent $112 \mathrm{~K}$ form to the secreted form of sgs-3. One possible function of sgs-3 glycosylation may be to make the protein soluble; the in vitro translation product of the sgs-3 mRNA (RNA IV) would not enter SDS-polyacrylamide gels, whereas the glycosylated sgs-3 protein does. Chemical deglycosylation of at least one soluble mammalian glycoprotein has been shown to render it insoluble in a wide variety of aqueous buffers (9).

That the molecular weights determined for sgs-7 and sgs-8 by SDS-PAGE were close to those predicted from the gene sequences implies that these glue polypeptides are not extensively glycosylated. This is consistent with the finding of Beckendorf and Kafatos (5) that their glue fraction P6, which probably includes sgs-7 and sgs-8, was not stained by the periodic acid-Schiff reaction, which stains most carbohydrates. It is possible to make a rough estimation of the isoelectric point expected of a polypeptide from its amino acid sequence (32). If this is done for sgs- 7 the expected $\mathrm{pI}$ is in the approximate range 7.5 to 8.5 ; sgs-8 would be expected to have a pI in the approximate range 7.2 to 8.2 . That the measured pI of sgs-7 is $\mathbf{1 0 . 3}$ may indicate that some sort of prosthetic group is attached to it or that some other modification has occurred. The two different isoelectric forms of sgs- 8 that are seen after migration in some gel types also imply that some sort of post-translational modification in addition to removal of the signal peptide may be suffered by at least one form of this protein.

One question raised by the demonstration that the 68C puff codes for three glue proteins derives from the investigation of Beckendorf and Kafatos (5) of the developmental times of synthesis of the salivary gland secretion polypeptides. Their observation was that their fraction P1, or sgs-3, and fraction P6, which probably includes sgs-7 and sgs-8, had very different developmental profiles in third-instar larvae. Observations on the RNAs now known to code for these polypeptides (19; Crowley, Kendall, and Meyerowitz, unpublished observations) indicate that their developmental profiles may be identical. More detailed observations of the developmental regulation of both RNA and protein will be necessary to find whether this RNAprotein difference is a consequence of differential control of translation of the $68 \mathrm{C}$ mRNAs.

\section{ACKNOWLEDGMENTS}

We thank M. Garfinkel and R. Pruitt for DNA sequence information and discussions during the course of this work, $H$. Mitchell for performing the larval injections, J. Bell for assistance with the protein sequencing, M. McMillan for providing the computer program used to convert counts per minute to disintegrations per minute, and $\mathbf{E}$. Lujan for performing the protein electrodialysis before sequencing. We also thank J. Kobori and S. Scherer for their critical reading of this manuscript.

This work was supported by a Public Health Service grant to E.M.M. from the National Institute of General Medical Sciences. M.W.B. was supported by a Public Health Service individual postdoctoral fellowship from the National Institutes of Health, and T.E.C. was supported by a National Research Service Award from the National Institute of General Medical Sciences.

\section{LITERATURE CITED}

1. Akam, M. E., D. B. Roberts, G. P. Richards, and M. Ashburner. 1978. Drosophila: the genetics of two major larval proteins. Cell 13:215-225.

2. Alwine, J. C., D. J. Kemp, B. A. Parker, J. Reiser, J. Renart, G. R. Stark, and G. M. Wahl. 1980. Detection of specific RNAs or specific fragments of DNA by fractionation in gels and transfer tò diazobenzyloxymethyl paper. Methods Enzymol. 68:220-242.

3. Ashburner, M. 1967. Patterns of puffing activity in the salivary gland chromosomes of Drosophila. I. Autosomal puffing patterns in a laboratory stock of Drosophila melanogaster. Chromosoma 21:398-428.

4. Ashburner, M., and G. Richards. 1976. Sequential gene activation by ecdysone in polytene chromosomes of Drosophila melanogaster. III. Consequences of ecdysone withdrawal. Dev. Biol. 54:241-255.

5. Beckendorf, S. K., and F. C. Kafatos. 1976. Differentiation in the salivary gland of Drosophila melanogaster: charac- 
terization of the glue proteins and their developmental appearance. Cell 9:365-373.

6. Blobel, G., and B. Dobberstein. 1975. Transfer of proteins across membranes. I. Presence of proteolytically processed and unprocessed nascent immunoglobulin light chains on membrane-bound ribosomes of murine myeloma. J. Cell Biol. 67:835-851.

7. Dickerson, R. E., and I. Geis. 1969. The structure and action of proteins. W. A. Benjamin, Inc., Menlo Park, Calif.

8. Fraenkel, G., and V. J. Brookes. 1953. The process by which the puparia of many species of flies become fixed to a substrate. Biol. Bull. 105:442-449.

9. Glassman, J. N. S., C. W. Todd, and J. E. Shiveley. 1978 Chemical deglycosylation of carcinoembryonic antigen for amino acid sequence studies. Biochem. Biophys. Res. Commun. 85:209-216.

10. Gronemeyer, H., and O. Pongs. 1980. Localization of ecdysterone on polytene chromosomes of Drosophila melanogaster. Proc. Natl. Acad. Sci. U.S.A. 77:21082112.

11. Gross, E. 1967. The cyanogen bromide reaction. Methods Enzymol. 11:238-255.

12. Grossbach, V. 1969. Chromosome-aktivität und biochemische zelldifferenzierung in den speicheldrüsen von Camptochironomus. Chromosoma 28:136-187.

13. Hunkapiller, M. W., and L. E. Hood. 1980 . New protein sequenator with increased sensitivity. Science 207:523525.

14. Kodani, M. 1948. The protein of the salivary gland secretion in Drosophila. Proc. Natl. Acad. Sci. U.S.A. 34:131135.

15. Korge, G. 1975. Chromosome puff activity and protein synthesis in larval salivary glands of Drosophila melanogaster. Proc. Natl. Acad. Sci. U.S.A. 72:4550-4554.

16. Korge, G. 1977. Larval saliva in Drosophila melanogaster: production, composition and relationship to chromosome puffs. Dev. Biol. 58:339-355.

17. Loemmli, U. K. 1970 . Cleavage of structural proteins during the assembly of the head of bacteriophage T4. Nature (London) 227:680-685.

18. Meyerowitz, E. M., G. M. Guild, L. S. Prestidge, and D. S. Hogness. 1980. A new high-capacity cosmid vector and its use. Gene 11:271-282.

19. Meyerowitz, E. M., and D. S. Hogness. 1982. Molecular organization of a Drosophila puff site that responds to ecdysone. Cell 28:165-176.

20. Mitchell, H. K. 1978. An apparatus for microinjection of Drosophila, p. 150-158. In M. Ashburner and T. R. F. Wright (eds.), Genetics and biology of drosophila. Academic Press, Inc., London.

21. Mitchell, H. K., P.-S. Chen, L. S. Lipps, and G. Moller. 1978. Separation of Drosophila RNAs on acrylamide gels in formamide. Insect Biochem. 8:29-35.

22. Muskavitch, M. A. T., and D. S. Hogness. 1980. Molecular analysis of a gene in a developmentally regulated puff of Drosophila melanogaster. Proc. Natl. Acad. Sci. U.S.A. 77:7362-7366.

23. O'Farrell, P. H. 1975. High resolution two-dimensional electrophoresis of proteins. J. Biol. Chem. 250:4007-4021

24. O'Farrell, P. Z., H. M. Goodman, and P. H. O'Farrell. 1977. High resolution two-dimensional electrophoresis of basic as well as acidic proteins. Cell 12:1133-1141.

25. Pelham, H. R. B., and R. J. Jackson. 1976. An efficient mRNA-dependent translation system from reticulocyte lysates. Eur. J. Biochem. 67:247-256.

26. Seed, B. 1982. Diazotizable arylamine cellulose papers for the coupling and hybridization of nucleic acids. Nucleic Acids Res. 10:1799-1810.

27. Segrest, J. P., and R. L. Jackson. 1972. Molecular weight determination of glycoproteins by polyacrylamide gel electrophoresis in sodium dodecyl sulfate. Methods Enzymol. 28:54-63.

28. Swank, R. T., and K. D. Munkres. 1971. Molecular weight analysis of oligopeptides by electrophoresis in polyacrylamide gels with sodium dodecyl sulfate. Anal. Biochem. 39:462-477.

29. Tissières, A., H. K. Mitchell, and U. M. Tracy. 1974. Protein synthesis in salivary glands of Drosophila melanogaster: relation to chromosome puffs. J. Mol. Biol. 84:389-398.

30. Velissariou, V., and M. Ashburner. 1980. The secretory proteins of the larval salivary glands of Drosophila melanogaster. Chromosoma 77:13-27.

31. Velissariou, V., and M. Ashburner. 1981. Cytogenetic and genetic mapping of a salivary gland secretion proteir in Drosophila melanogaster. Chromosoma 84:173-185.

32. White, A., P. Handler, E. L. Smith, R. L. Hill, and I. R. Lehman. 1978. Principles of biochemistry, 6th ed. McGraw-Hill Book Co., New York. 